\title{
Warning systems in a computerized nursing process for Intensive Care Units*
}

\author{
SISTEMAS DE ALERTA EM UM PROCESSO DE ENFERMAGEM INFORMATIZADO PARA \\ UNIDADES DE TERAPIA INTENSIVA
}

\section{SISTEMAS DE ALERTA EN EL PROCESO DE ENFERMERÍA INFORMATIZADO EN UNIDADES DE TERAPIA INTENSIVA}

\section{Daniela Couto Carvalho Barra', Grace Teresinha Marcon Dal Sasso², Camila Rosália Antunes Baccin ${ }^{3}$}

\begin{abstract}
A hybrid study combining technological production and methodological research aiming to establish associations between the data and information that are part of a Computerized Nursing Process according to the ICNP ${ }^{\circledR}$ Version 1.0, indicators of patient safety and quality of care. Based on the guidelines of the Agency for Healthcare Research and Quality and the American Association of Critical Care Nurses for the expansion of warning systems, five warning systems were developed: potential for iatrogenic pneumothorax, potential for care-related infections, potential for suture dehiscence in patients after abdominal or pelvic surgery, potential for loss of vascular access, and potential for endotracheal extubation. The warning systems are a continuous computerized resource of essential situations that promote patient safety and enable the construction of a way to stimulate clinical reasoning and support clinical decision making of nurses in intensive care.
\end{abstract}

\section{DESCRIPTORS}

Nursing process

Reminder systems

Nursing informatics

atient safety

Intensive Care Units

\section{RESUMO}

Estudo híbrido que combinou produção tecnológica e pesquisa metodológica com o objetivo de estabelecer associações entre os dados e as informações que integram um Processo de Enfermagem Informatizado baseado na $\mathrm{CIPE}^{\circledR}$ versão 1.0 , indicadores de segurança do paciente e indicadores de qualidade do cuidado. Fundamentados nas orientações da Agency for Healthcare Research and Quality e da American Association of Critical Care Nurses para a ampliação dos sistemas de alerta, foram desenvolvidos cinco sistemas de alerta: potencial para pneumotórax iatrogênico, potencial para infecções secundárias ao cuidado prestado, potencial para deiscência de sutura no pós-operatório de pacientes de cirurgia abdominal ou pélvica, potencial para perda de acesso vascular e potencial para extubação endotraqueal. Os sistema de alerta são um recurso informatizado contínuo de situações essenciais que promove a segurança do paciente e permite construir um modo de estimular o raciocínio clínico e apoiar a tomada de decisão clínica do enfermeiro em Terapia Intensiva.

\section{DESCRITORES}

Processos de enfermagem istemas de alerta Informática em enfermagem Segurança do paciente Unidades de Terapia Intensiva

\section{RESUMEN}

Estudio híbrido de producción de tecnología y de investigación metodológica. El objetivo fue establecer las asociaciones entre: los datos y la información que integra el Proceso de Enfermería Informatizado a partir de la CIPE ${ }^{\circledR}$ versión 1.0, los indicadores de Seguridad del Paciente y los Indicadores de la Calidad de la Atención, a partir de la orientación de la Agency for Healthcare Research and Quality y de la American Association of Critical-Care Nurses para la expansión de los sistemas de alerta. Se desarrollaron cinco sistemas de alerta para los siguientes problemas potenciales: neumotórax iatrogénico, infecciones secundarias a la atención de salud, dehiscencia de herida quirúrgica abdominal o pélvica en pacientes en el postoperatorio, pérdida del acceso vascular y extubación endotraqueal. Los sistemas de alerta son un recurso informatizado continuo de situaciones esenciales que promueven la seguridad del paciente y que permiten además de construir un modo de estimular el raciocinio clínico, apoyar la toma de decisiones clínicas de enfermería en terapia intensiva.

\section{DESCRIPTORES \\ Procesos de enfermeira Sistemas recordatorios Informática Aplicada a la Enfermería Seguridad del paciente Unidades de Cuidados Intensivos}

\footnotetext{
* Extracted from the thesis "Processo de enfermagem informatizado e a segurança do paciente em terapia intensiva a partir da CIPE® versão 1.0: a evidência clínica para o cuidado", Nursing Graduate Program, Federal University of Santa Catarina, 2012. ${ }^{1}$ Doctorate in Nursing, Federal University of Santa Catarina, Florianópolis, SC, Brazil danyccbarra@gmail.com.br ${ }^{2}$ Doctoratein Nursing. Adjunct Professor, Department of Nursing and the Nursing Graduate Program, Federal University of Santa Catarina, Florianópolis, SC, Brazil. ${ }^{3}$ Master's degree in Nursing. Professor at Planalto Catarinense University, Lages, SC, Brazil.
} camilabaccin@gmail.com 


\section{INTRODUCTION}

There is currently a broad world consensus among organizations and health services regarding the need for the reduction of injuries or adverse events in patients.

Among the various health care environments, Intensive Care Units (ICU) stand out as environments in which the focus on patient safety should be strongly present. In those units, patients are more prone to the occurrence of errors and adverse events, due to: the severity and seriousness of the disease, increased frequency of pharmacological and therapeutic interventions, and the use of various technological devices ${ }^{(1-2)}$.

Most adverse events in the ICU are related to failures in the prevention and diagnosis of diseases, in drug treatment, in the monitoring system and in the interpretation of the monitors by professionals, in addition to failures related to indication, placement, maintenance and withdrawal of accesses, tubes and drains ${ }^{(3-6)}$.

It is believed that some technical changes can improve safety for patients, including the implementation of electronic medical records structured according to global terminologies and classification systems and awareness of health professionals to the safety and quality of care.

Electronic health records are relevant sources of information for monitoring the levels of quality and safety. Such records should prioritize quality and reliability. When making records using the Nursing Process (NP), professionals should adopt a method that supports the reliability of data collection in order to establish the quality of the indicators assessed ${ }^{(7-8)}$, improve and support patient safety, ensure quality of care and give visibility to the everyday nursing actions ${ }^{(9-11)}$.

Since 1999, a proposal for a Computerized Nursing Process (CNP) developed by the Department of Nursing of the Federal University of Santa Catarina, based on the International Classification for Nursing Practice (ICNP ${ }^{\circledR}$ ) Version 1.0 for ICUs has been implemented and assessed by nurses, professors and system programmers. In each study, the CNP has been assessed and modifications have been introduced.

In 2006, for example, an information structure proposal via Web was reached that met the demands of nursing care of patients with multiple traumas in the ICU. In 2008, the structure of the NP information system was constructed, implemented and assessed in a Personal Digital Assistant (PDA) mobile device integrated to a previously developed computerized system via Web ${ }^{(12)}$.

The CNP based on the ICNP ${ }^{\circledR}$ Version 1.0 is available via the Web at: <http://www.nfrinfor.ufsc.br> and <http://www.nfrinfor.ufsc.br/movel> for both desktop and mobile devices. It can be accessed through the provision of login and password provided by the system administrators. The CNP suggests a group of diagnoses based on the assessment of clinical changes presented by the patient and then another group of nursing interventions for the diagnoses chosen by nurses, i.e., the nursing diagnoses are specific for each clinical situation or change presented by the patient during the assessment and interventions are specific for the diagnoses presented ${ }^{(12-13)}$.

In the CNP structure, warning systems were introduced through features of Information and Communication Technologies (ICT). Built in 2006, such systems were aimed at early identification of the ICU patient's risks in three specific situations, and at supporting nurses in decision-making about nursing care and patient safety. The warnings could be visualized in the Web-based computerized system on the clinical conditions and nursing diagnoses selected during the nurses' assessment.

When the message warning is seen in the CNP, nurses checked that three situations could be occurring: I) the same nursing diagnosis for over three days, and/ or, II) use of vasoactive drugs in adrenergic alpha $(\alpha)$ or beta $(\beta)$ doses and/or; III) potential for pressure ulcers. In order to know which of these three warning systems the patient had, professionals would simply click on the warning sign and she would be automatically directed to an initial assessment screen where the warning was shown, highlighted in red.

The positive assessment of the professionals about the changes implemented in both the desktop system (via WEB) and the mobile system (via PDA) enabled the conclusion that such systems were accessible and usable to implement the CNP in ICUs and contributed to nursing clinical decision-making regarding care and patient safe$t^{(12-14)}$. Some recommendations for future work were suggested, among them the expansion of new warning systems for the CNP.

The objective of the present study was to establish associations between the data and information that are part of the CNP, according to the ICNP ${ }^{\circledR}$ Version 1.0, indicators of patient safety and quality of care, based on guidelines from the Agency for Healthcare Research and Quality (AHRQ) and the American Association of Critical-Care Nurses (AACN), for the extension of the warning systems.

\section{METHOD}

It was a hybrid study combining technological production and methodological research ${ }^{(15)}$ for the expansion of warning systems for the CNP, according to the ICNP ${ }^{\circledR}$ Version 1.0. It was submitted to the Ethics Research Committee of the Federal University of Santa Catarina (CEP-UFSC), and approved under protocol 466/12.
Warning systems in a computerized nursing process for Intensive Care Units Barra DCC, Dal Sasso GTM, Baccin CRA 
The professionals that participated in its construction were a doctorally-prepared professor, specialist in ICU and in Nursing Health Informatics, two graduated nurses, and one systems programmer who graduated in Computer Sciences. The participants (except for the systems programmer) were also the evaluators of the study, because they were specialists in ICU and Emergency and developed research activities with the ICNP ${ }^{\circledR}$ Version 1.0 in the Clinical Research, Technology, Health Informatics and Nursing Group at the Federal University of Santa Catarina (GIATE/PEN/UFSC) since 2003.

The study was performed between the second semester 2011 and the first semester 2012, through the development of the following phases. In the First phase, there was a theoretical study on the themes: patient safety in the ICU, patient safety indicators (PSIs), quality of care indicators, electronic nursing documentation and NP according to the ICNP ${ }^{\circledR}$ Version 1.0. Among the twenty AHRQ PSIs, those which were closest to nursing care in the ICU and which supported the development of new warning systems were chosen: I) potential for iatrogenic pneumothorax (PSI 6); II) potential for carerelated infections (PSI 7), and III) potential for suture dehiscence in patients after abdominal or pelvic surgery (PSI 14).

In the literature review on patient safety, it was found that two other warnings could be developed from the Nursing-sensitive Care Quality Indicators in ICU established by the American Association of Critical Care Nurses (AACN). Thereby, in order to minimize the occurrence of adverse events related to venous puncture and endotracheal intubation, two other warnings were defined: IV) potential for loss of vascular access, and V) potential for endotracheal extubation.

In the Second stage, a theoretical study on the Fuzzy Set Theory, Fuzzy Logic concepts and Fuzzy Inference Systems was performed. This stage was essential to understand the production rules called if ... then, used to establish associations between data in the CNP (clinical assessment, nursing diagnosis and interventions for each human system) for the development of new warning systems.

Although formal logic states that if the patient has a particular health problem, then a given change/clinical manifestation should be established, in Fuzzy Logic reasoning and clinical judgment involve various fuzzy paths, since the clinical manifestations are individual and encompass a series of subjective and objective judgment structures.

The Fuzzy Sets Theory and Fuzzy Logic concepts provide the necessary mathematical tools to deal with linguistic rules used in Fuzzy Inference Systems. Such systems seek to establish the mode of reasoning by means of linguistic rules that attempt to mimic the human ability to make rational decisions through objective knowledge in an environment of uncertainty and imprecision. If an individual is able to establish/coordinate his action strategy as a set of linguistic rules, such as implication operator if ... then, it becomes feasible to build an algorithm to be implemented within a computer ${ }^{(16-17)}$.

It is noteworthy that the composition of relations is of fundamental importance in Fuzzy Inference Systems. In this study we chose to adopt the implication operator if... then. This operator, also known as fuzzy conditional statement, describes the dependence of the value of a linguistic variable on the value of another ${ }^{(16-17)}$, i.e., the conditional/linguistic rules consist of statements such as, if patient has a deep vascular access, then there is potential for loss of vascular access.

In the Third stage, an association between the data of the clinical assessment, diagnoses and interventions of every human system for the new warnings established was performed by using the conditional statements and linguistic rules associated with the implication operator if... then. This stage was accomplished through weekly meetings and was considered the most complex because it required the integration of professional practice and theory by the researchers, the development of clinical reasoning and judgment on the many possibilities of association that could occur for the development of each new warning system.

The association/articulation of the data resulted from the grouping of possible clinical situations and/or nursing diagnoses and/or interventions for every human system that could be selected by the nurse during the record/clinical documentation in the CNP, leading to the generation of the corresponding warning system.

In the Fourth stage, a general meeting was held to review the associations and enter the data into a spreadsheet, using Excel $^{\circledR}$, and later into the computerized system. This step was performed in conjunction with the systems programmer specialist in Computer Sciences.

\section{RESULTS}

In the warning systems potential for iatrogenic pneumothorax and potential for care-related infections, patients may show any clinical situation and/or nursing diagnosis and/or intervention for the warning to be generated. It is not necessary that all the items of a set of conditional statements are selected by the nurse. That means that, when selecting any of the items of clinical assessment, nursing diagnosis or interventions of either human system contemplated, warnings are triggered in the system.

For the warning system potential for iatrogenic pneumothorax, clinical data, nursing diagnoses and interventions of the respiratory, cardiovascular and musculoskele- 
tal systems were associated. Chart 1 shows the association held in the respiratory system.

For the Warning system potential for care-related infections, it was necessary to establish associations of data and information from virtually all human systems that integrate the CNP, since patients admitted to the ICU are exposed to the occurrence of infections due to the gravity of diseases and invasive therapeutic procedures. Thereby, data of respiratory, cardiovascular, musculoskeletal, gastrointestinal, renal, and integumentary systems were associated. Thus, the presence of conditional statements within any of the human systems assessed by nurses was sufficient to trigger the alarm. Chart 2 shows the associations established in the gastrointestinal and renal systems, as an example.

For the warning, potential for suture dehiscence in patients after abdominal or pelvic surgery, patients must have undergone an abdominal and/or pelvic surgery. This warning was covered only with a combination of data and information provided in the integumentary system, in which case nurses must, without fail, select the item in the clinical assessment, Wound healing: primary, secondary or tertiary intention. In that same human system, they must select the diagnoses compromised surgical wound and/or compromised abdominal or pelvic surgical wound for the warning to be generated by the CNP and visualized by the professional.

For the warning system potential for loss of vascular access and potential for endotracheal extubation, developed from the Nursing-Sensitive Quality Indicators in the ICU established by the AACN, patients must have peripheral and/or deep vascular access and be intubated and mechanically ventilated, respectively.

For the warning system potential for loss of vascular access, clinical data from the nursing diagnoses of the cardiovascular system were comprehended, and for the warning, potential for endotracheal extubation, clinical data, nursing diagnoses and interventions of the respiratory system.

The three warning systems, potential for suture dehiscence in patients after abdominal or pelvic surgery, potential loss of vascular access, and potential for endotracheal extubation - have mandatory selection criteria so that they can be generated by the system. They may or may not be associated with other clinical data, nursing diagnoses and interventions present in other human systems, as explained in Chart 3.

Chart 1 - Association of the CNP data for the construction of the warning system Potential for iatrogenic pneumothorax.

\begin{tabular}{|c|c|c|}
\hline CNP data & $\begin{array}{l}\text { Conditional statements/ } \\
\text { Linguistic rules "IF" }\end{array}$ & “THEN" \\
\hline $\begin{array}{l}\text { Respiratory } \\
\text { System } \\
\text { Clinical } \\
\text { Assessment }\end{array}$ & $\begin{array}{l}\text { - Vital Signs: }<90 / 60 \mathrm{mmHg} \text { or HR }>100 \mathrm{bpm} \text { or RR }>20 \mathrm{bpm} \text { or MAP }<60 \mathrm{mmHg} \text { or CVP/RAP }>10 \mathrm{mmHg} \\
\text { PVC } \\
\text { - Respiratory Rhythm: Irregular and deep or irregular and superficial } \\
\text { - Perfusion/Saturation: generalized cyanosis or cyanosis of the extremities } \\
\text { - Oxygenation : Mechanical ventilation through ETT/Tracheostomy. Ventilation mode : controlled volume or } \\
\text { pressure; FIO2 }>50 \% \text {, Peak Pressure }>20 \mathrm{cmH} 2 \mathrm{O}, \mathrm{PEEP}>10 ; \text { Cuff pressure }>30 \mathrm{mmHg} \text {, TOT positioning }<20 \\
\mathrm{~cm} \\
\text { - Respiration: dyspnea } \\
\text { - Cough/Sputum : productive with secretion } \\
\text { - Breath Sounds : reduced or absent ventilatory movements in both lung bases; reduced or absent in the right } \\
\text { or left bases; reduced or absent in both lung apices; reduced or absent in the right or left apices; diffuse rhon- } \\
\text { chi, diffuse rales } \\
\text { - Aspiration: ETT/Tracheostomy: with secretion } \\
\text { - X-ray: Fracture of right or left rib, pneumothorax on the left or on the right, chest tube on the left or on the } \\
\text { right, atelectasis on the left or on the rigtht, atelectasis } \\
\text { Drains: chest in the left and/or in the right; mediastinum }\end{array}$ & \multirow{3}{*}{$\begin{array}{l}\text { WARNING } \\
\text { "Potential } \\
\text { for iatrogenic } \\
\text { pneumothorax" }\end{array}$} \\
\hline $\begin{array}{l}\text { Respiratory } \\
\text { System } \\
\text { Nursing } \\
\text { diagnoses ac- } \\
\text { cording to the } \\
\text { ICNP }{ }^{\circledR} 1.0\end{array}$ & $\begin{array}{l}\text { Increased pulmonary congestion, severe pulmonary congestion; dependent on mechanical ventilation in con- } \\
\text { trolled pressure; dependent on mechanical ventilation in controlled volume; increased dyspnea during small } \\
\text { and medium efforts; severe hypoxia, inadequate gas parameters; inadequate tissue perfusion and saturation; } \\
\text { potential for increased hypoxia; inadequate respiratory process; inadequate ventilatory response; compromised } \\
\text { respiratory system, increased cough and sputum; inadequate gas exchange. }\end{array}$ & \\
\hline $\begin{array}{l}\text { Respiratory } \\
\text { System } \\
\text { Nursing } \\
\text { interventions } \\
\text { according to } \\
\text { the ICN }{ }^{\circledast} 1.0\end{array}$ & $\begin{array}{l}\text { - Assess blood gases: if hypoxemia, administer supplemental O2. } \\
\text { - Assess breathing pattern if spontaneously breathing (frequency, expansibility, compliance and rhythm). } \\
\text { - Assess ventilatory pattern in mechanical ventilation mode (sync, alarms, PEEP, peak pressure, FIO2, tidal } \\
\text { volume, condensed in the trachea, the level of the trachea). } \\
\text { - Assess tissue perfusion and saturation (extremities, lips, eyes, tip of ear). } \\
\text { - Assess the chest for the presence of flail chest, tumor, lesion, asymmetry, etc. } \\
\text { - Examine the characteristics of the chest and mediastinum drainage } 6 / 6 \mathrm{~h} \text { or more if necessary } \\
\text { - Monitor and interpret blood gas values (PO2, pH, } \mathrm{BE}, \mathrm{HCO}, \mathrm{PCO}, \mathrm{SpO} 2) \\
\text { - Monitor and check vital signs } \\
\text { - Monitor peripheral oximetry and capnography hourly. Monitor signs of hypoxemia and hypercapnia } \\
\text { (psychomotor agitation, cyanosis, sweating, pallor, competition with machine ventilation) }\end{array}$ & \\
\hline
\end{tabular}


Chart 2 - Association of the CNP data for the construction of the Warning system Potential for care-related infections.

\begin{tabular}{|c|c|c|}
\hline CNP data & $\begin{array}{l}\text { Conditional statements/ } \\
\text { Linguistic rules "IF" }\end{array}$ & "THEN" \\
\hline $\begin{array}{l}\text { Gastrointestinal system } \\
\text { Clinical assessment }\end{array}$ & $\begin{array}{l}\text { - Tube placing: jejunum; Sengtaken-Blackmore; Nasoenteral tube; Nasogastric tube; Gavage; } \\
\text { Gastrostomy } \\
\text { - Oral mucosa: bleeding gums; gingivitis; candidiasis, herpes, gingival lesions; cleft lips } \\
\text { - Incisão cirúrgica: aberta ou fechada }\end{array}$ & \multirow{3}{*}{$\begin{array}{l}\text { WARNING } \\
\text { "Potential for } \\
\text { care-related } \\
\text { infections" }\end{array}$} \\
\hline $\begin{array}{l}\text { Gastrointestinal system } \\
\text { Nursing diagnoses ac- } \\
\text { cording to the ICNP }{ }^{\circledR} 1.0\end{array}$ & $\begin{array}{l}\text { - Altered gastric contents; } \\
\text { - Severe or moderate to mild abdominal colic; } \\
\text { - Severe or mild or moderate diarrhea; } \\
\text { - Impaired nutrition; } \\
\text { - Increased intra-abdominal pressure; } \\
\text { - Compromised digestive process; } \\
\text { - Impaired nutritional status. }\end{array}$ & \\
\hline $\begin{array}{l}\text { Gastrointestinal system } \\
\text { Nursing interventions ac- } \\
\text { cording to the } \mathrm{ICN}^{\circledR} 1.0\end{array}$ & $\begin{array}{l}\text { - Observe signs of infection at the surgical incision } \\
\text { - Install or assist in Sengstaken-Blakemore balloon installation. } \\
\text { - Clamp Sengstaken-Blakemore balloon immediately } \\
\text { - Maintain functioning and permeability of tubes } \\
\text { - Assess the position of the nasoenteral tube before starting the infusion of diet }\end{array}$ & \\
\hline $\begin{array}{l}\text { Renal system } \\
\text { Clinical assessment }\end{array}$ & $\begin{array}{l}\text { - Pain: suprapubic, back or flank } \\
\text { - Characteristics of diuresis: dysuria } \\
\text { - Injury to the urethra: wound or perforation } \\
\text { - Types of diuresis: Foley tube } 2 \text { or } 3 \text { ways; peritoneal dialysis, hemodialysis; suprapubic aspira- } \\
\text { tion; indwelling urinary catheter }\end{array}$ & \multirow[b]{3}{*}{$\begin{array}{l}\text { WARNING } \\
\text { "Potential for } \\
\text { care-related } \\
\text { infections" }\end{array}$} \\
\hline $\begin{array}{l}\text { Renal system } \\
\text { Nursing diagnoses accord- } \\
\text { ing to the ICNP }{ }^{\circledR} 1.0\end{array}$ & $\begin{array}{l}\text { - Compromised urinary system process } \\
\text { - Risk for infection }\end{array}$ & \\
\hline $\begin{array}{l}\text { Renal system } \\
\text { Nursing interventions ac- } \\
\text { cording to the } \mathrm{ICN}^{\circledR} 1.0\end{array}$ & $\begin{array}{l}\text { - Assess and record the characteristics of diuresis: color, appearance, density } \\
\text { - Clamp urinary catheter when transporting the patient } \\
\text { - Sanitize hands before and after insertion or manipulation of the urinary catheter and its attach- } \\
\text { ments } \\
\text { - Keep the permeability of the urinary catheter, observing the presence of clots and lumps } \\
\text { - Keep collection bag below the bladder level without touching the ground } \\
\text { - Keep the flow clear and sterile and to continuous drainage } \\
\text { - Maintain closed drainage system } \\
\text { - Measure the volume drained in the collection bag often using clean, individualized containers, } \\
\text { avoiding leakages and catheter contamination } \\
\text { - Perform hygiene on the urinary meatus } \\
\text { - Change urinary catheter and drainage system if aseptic technique is broken, disconnection or } \\
\text { leakage occur }\end{array}$ & \\
\hline
\end{tabular}

Chart 3 - Association of the CNP data for the construction of the warning system, potential for suture dehiscence in patients after abdominal or pelvic surgery, potential for loss of vascular access, and potential for endotracheal extubation.

\begin{tabular}{|c|c|c|}
\hline \multicolumn{3}{|c|}{ POTENTIAL FOR SUTURE DEHISCENCE IN PATIENTS AFTER ABDOMINAL OR PELVIC SURGERY } \\
\hline CNP data & $\begin{array}{l}\text { Conditional statements/ } \\
\text { Linguistic rules "IF" }\end{array}$ & “THEN" \\
\hline $\begin{array}{l}\text { Integumentary system } \\
\text { Clinical assessment }\end{array}$ & - Wound Healing - primary, secondary or tertiary intention (mandatory selection) & \multirow{2}{*}{$\begin{array}{l}\text { WARNING } \\
\text { "Potential } \\
\text { for suture } \\
\text { dehiscence in } \\
\text { patients after } \\
\text { abdominal or } \\
\text { pelvic surgery" }\end{array}$} \\
\hline $\begin{array}{l}\text { Integumentary system } \\
\text { Nursing diagnoses according } \\
\text { to the ICNP }{ }^{\circledR} 1.0\end{array}$ & $\begin{array}{l}\text { - Compromised surgical wound (mandatory selection) } \\
\text { - Compromised abdominal or pelvic surgical wound (mandatory selection) } \\
\text { - Increased body temperature }\end{array}$ & \\
\hline \multicolumn{3}{|c|}{ POTENTIAL FOR LOSS OF VASCULAR ACCESS } \\
\hline CNP data & $\begin{array}{c}\text { Conditional statements/ } \\
\text { Linguistic rules "IF" }\end{array}$ & "THEN" \\
\hline $\begin{array}{l}\text { Cardiovascular } \\
\text { System } \\
\text { Clinical assessment }\end{array}$ & $\begin{array}{l}\text { - Vascular access: peripheral and/or deep (mandatory selection) } \\
\text { - Skin: moist or profuse sweating } \\
\text { - Edema: lower extremities }\end{array}$ & \multirow{2}{*}{$\begin{array}{l}\text { WARNING } \\
\text { "Potential for } \\
\text { loss of vascular } \\
\text { access" }\end{array}$} \\
\hline $\begin{array}{l}\text { Cardiovascular } \\
\text { System } \\
\text { Nursing diagnoses according } \\
\text { to the ICNP }{ }^{\circledR} 1.0\end{array}$ & $\begin{array}{l}\text { - Abnormal IV access } \\
\text { - Moderate or severe anasarca } \\
\text { - Moderate or severe edema } \\
\text { - Inadequate venous circulatory process } \\
\text { - Altered vascular process }\end{array}$ & \\
\hline
\end{tabular}




\begin{tabular}{|c|c|c|}
\hline \multicolumn{3}{|c|}{ POTENTIAL FOR ENDOTRACHEAL EXTUBATION } \\
\hline CNP data & $\begin{array}{l}\text { Conditional statements/ } \\
\text { Linguistic rules "IF" }\end{array}$ & "THEN" \\
\hline $\begin{array}{l}\text { Respiratory System } \\
\text { Clinical assessment }\end{array}$ & $\begin{array}{l}\text { - Oxygenation : Mechanical ventilation through ETT/tracheostomy (mandatory selection) } \\
\text { Ventilation mode : Controlled volume or pressure; FIO2 }>50 \% \text {, Peak Pressure }>20 \mathrm{cmH} 2 \mathrm{O} \text {, } \\
\text { PEEP }>10 \text {; Cuff pressure }>30 \mathrm{mmHg} \text {, TOT positioning }<20 \mathrm{~cm} \\
\text { - Respiratory rhythm: irregular and deep or irregular and superficial } \\
\text { - Perfusion/saturation: generalized cyanosis or cyanosis of the extremities } \\
\text { - Respiration : dyspnea } \\
\text { - Cough/sputum : productive with secretion } \\
\text { - Aspiration: ETT/tracheostomy: with secretion }\end{array}$ & \multirow{3}{*}{$\begin{array}{l}\text { WARNING } \\
\text { "Potential for } \\
\text { endotracheal } \\
\text { extubation" }\end{array}$} \\
\hline $\begin{array}{l}\text { Respiratory System } \\
\text { Nursing diagnoses according } \\
\text { to the ICNP }{ }^{\circledR} 1.0\end{array}$ & $\begin{array}{l}\text { - Increased cough and with expectoration } \\
\text { - Inadequate gas exchange } \\
\text { - Increased or severe pulmonary congestion } \\
\text { - Dependent on pressure controlled mechanical ventilation } \\
\text { - Dependent on volume-controlled mechanical ventilation } \\
\text { - Increased dyspnea during small and medium efforts; } \\
\text { - Severe hypoxia } \\
\text { - Inadequate blood gas parameters } \\
\text { - Inadequate tissue perfusion and saturation } \\
\text { - Potential for increased hypoxia } \\
\text { - Inadequate breathing response } \\
\text { - Inadequate ventilatory response } \\
\text { - Compromised respiratory system } \\
\text { - Increased cough and sputum }\end{array}$ & \\
\hline $\begin{array}{l}\text { Respiratory System } \\
\text { Nursing interventions accord- } \\
\text { ing to the ICN }{ }^{\circledR} 1.0\end{array}$ & $\begin{array}{l}\text { - Assess ventilatory pattern in the mode of mechanical ventilation (sync, alarms, PEEP, Peak } \\
\text { pressure, FIO2, tidal volume, condensed in the trachea, the level of the trachea). } \\
\text { - Assess tissue perfusion and saturation (extremities, lips, eyes, tip of ear). } \\
\text { - Monitor and interpret blood gas values (PO2, pH, BE, HCO3, PCO2, SpO2) } \\
\text { - Monitor and check vital signs } \\
\text { - Monitor peripheral oximetry and capnography hourly. } \\
\text { - Monitor signs of hypoxemia and hypercapnia (psychomotor agitation, cyanosis, sweating, } \\
\text { pallor, competition with machine ventilation) }\end{array}$ & \\
\hline
\end{tabular}

\section{DISCUSSION}

Considering all the discussions about patient safety, it is currently imperative that care-related risks of harm and adverse events are reduced to an acceptable minimum rate compared to updated knowledge, to the context in which health care is performed and technological resources are available $\mathrm{e}^{(18-19)}$.

Especially in the ICU, the quality of care provided can be assessed by indicators of a technical, educational, environmental, structural and ethical nature. In these environments, indicators can reflect positively on various aspects such as: greater recognition, visibility and professional respect; better informed health teams, higher rate of hospital occupancy and turnover of hospital beds, shorter hospitalization, waste control and cost rationalizing, improved quality of care, increased patient and family satisfaction, and greater safety for the patient and others ${ }^{(20)}$.

By extending the Warning systems from the establishment of the association of clinical data and information that comprise the CNP and the guidelines of $A R Q H$ and $A A C N$, it is understood that both PSI as nursing-sensitive indicators of quality enable the creation of systems and operational processes to minimize errors and maximize the likelihood of intercepting errors/adverse events before they occur ${ }^{(21)}$.
Patient Safety Indicators are a set of specific quality measures/indicators that reflect the quality of care in hospitals, focusing on aspects of patient safety and demonstrating the adverse events as a result of the experience of patients during exposure to the health care system.

The PSI were launched in March of 2003, by the AHRQ and National Healthcare Disparities Report (NHDR), both in the United States, providing a comprehensive vision and a vision on the changes in the level of quality of health care $^{(21-23)}$.

By establishing warning systems for the CNP according to the ICNP ${ }^{\circledR}$ version 1.0, a way to stimulate clinical reasoning and therefore to support clinical decision making of nurses in ICU was constructed. Reasoning and clinical decision-making are thought processes that guide practice, i.e., it is a dynamic process, composed of a sequence of thoughts of nurses in order to make decisions about their actions ${ }^{(24-26)}$.

The structured logic of data and information in the CNP is a path to clinical reasoning, which does not mean that such a structure is the standard for electronic recording in nursing. However, it was built on fundamental criteria for their development, such as the ICNP ${ }^{\circledR}$ Version 1.0; for$\mathrm{ms}$ of teaching and assessment in Brazil, evidence-based practice, patient safety and structure of alert systems. 
Warnings generated by the system do not replace decision making, but they are a technological feature that enables the development of a safer practice of care, preventing complications, damage and adverse events to the patient, and continuously stimulating clinical revisiting by nurses, approaching their care at the bedside.

The warnings are integrated into all stages of the CNP and are triggered when nurses perform all of any of the stages of the CNP (clinical assessment and/or diagnoses and/or interventions) of human systems which were associated with their respective warnings. That demonstrates that this technological product has great potential application in clinical nursing practice.

Structured according to the ICNP ${ }^{\circledR}$ Version 1.0, the CNP has several implications for research, including: establishing the situations of greater risk to the patient for the prevention of adverse events; assessing nursing care and outcomes; determining the accuracy of nursing diagnoses and interventions, and establishing measures of indicators of quality of care and patient safety.

One limitation of this study is that, although they have been extended, warning systems have not crossed the complexity of intensive nursing care, and it is necessary to develop new warnings to improve patient safety .

\section{REFERENCES}

1. Nascimento CCP, Toffoletto MC, Gonçalves LA, Freitas WG, Padilha KG. Indicators of healthcare results: analysis of adverse events during hospital stays. Rev Latino Am. Enferm [Internet]. 2008 [cited 2013 June11];16(4):746-51. Available from: http://www.scielo.br/pdf/rlae/v16n4/pt_15.pdf

2. Beccaria RLM, Pereira LAM, Contrin M, Lobo SMA, Trajano DHL. Eventos adversos na assistência de enfermagem em uma unidade de terapia intensiva. Rev Bras Ter Intensiva [Internet]. 2009 [citado 2013 jun. 11]; 21(3):276-82. Disponível em: http://www.scielo.br/pdf/rbti/v21n3/a07v21n3.pdf

3. Canineu R, Guimarães HP, Lopes RD, Vendrame LS, Fonseca Júnior MA, Lopes AC. latrogenia em medicina intensiva. Rev Bras Ter Intensiva [Internet]. 2006 [citado 2013 jun. 11];18(1):95-8. Disponível em: http://www.scielo.br/pdf/rbti/ v18n1/a15v18n1.pdf

4. Claro CM, Krocockz DVC, Toffolleto MC, Padilha KG. Adverse events at the Intensive Care Unit: nurses' perception about the culture of no-punishment. Rev Esc Enferm USP [Internet]. 2011 [cited 2013 June 11];45(1):167-72. Available from: http://www.scielo.br/pdf/reeusp/v45n1/en_23.pdf

5. Faria LMP, Cassiani SHB. Interação medicamentosa: conhecimento de enfermeiros das unidades de terapia intensiva. Acta Paul Enferm [Internet]. 2011 [citado 2013 jun. 11];24(2):264-70. Disponível em: http://www.scielo.br/ pdf/ape/v24n2/17.pdf

\section{CONCLUSION}

The use of resources made available by ICT enabled the association of clinical data and information, nursing diagnoses and interventions, according to the ICNP ${ }^{\circledR}$ Version 1.0, for the expansion of warning systems in the CNP.

Based on the guidelines of the Agency for Healthcare Research and Quality and the American Association of Critical Care Nurses, five new warning systems were developed: potential for iatrogenic pneumothorax; potential for care-related infections; potential for suture dehiscence in patients after abdominal or pelvic surgery; potential for loss of vascular access and potential for endotracheal extubation. Broadening warning systems according to the indicators of the AHRQ Patient Safety Indicators and AACN Nursing Quality Indicators may be a strategy to promote quality of care and patient safety in the ICU.

It is considered that the warning systems provide support to nurses to prevent the occurrence of injury and adverse events. This is an ongoing computerized resource of essential situations that promotes patient safety, stimulates clinical reasoning and judgment, and supports decision making by these professionals in the ICU.

6. Lima REF, Cassiani SHB. Potential drug interactions in intensive care patients at a teaching hospital. Rev Latino Am Enferm [Internet]. 2009 [cited 2013 June 11];17(2):222-7. Available from: http://www.scielo.br/pdf/rlae/v17n2/13.pdf

7. Evans SM, Lowinger JS, Sprivulis PC, Copnell B, Cameron PA. Prioritizing quality indicator development across the healthcare system: identifying what to measure. Intern Med J. 2009;39(10):648-54.

8. Labbadia LL, D'innocenzo M, Fogliano RRF, Silva EF, Queiroz RMRM, Carmagnani MIS, et al. Computerized system for managing nursing care indicators at Hospital São Paulo. Rev Esc Enferm USP [internet]. 2011 [cited 2013 June 11];45(4):10137. Available from: http://www.scielo.br/pdf/reeusp/v45n4/ en_v45n4a32.pdf

9. Lima CLH, Nóbrega MML. Banco de termos da linguagem especial de enfermagem da clínica médica. Rev Eletr Enferm [Internet]. 2009 [citado 2013 jun. 11];11(1):12-22. Disponível em: http://www.fen.ufg.br/fen_revista/v11/n1/pdf/ v11n1a02.pdf

10. Padilha EF, Matsuda LM. Qualidade dos cuidados de enfermagem em terapia intensiva: avaliação por meio de auditoria operacional. Rev Bras Enferm [Internet]. 2011 [citado 2013 jun. 11];64(4):684-91. Disponível em: http://www. scielo.br/pdf/reben/v64n4/a09v64n4.pdf 
11. Pyle K, Wavra T. Quality indicators for critical care. AACN Adv Crit Care. 2007; 18(3):229-43.

12. Barra DCC, Sasso GTMD. Mobile bedside technology: computerized nursing processes in intensive care unit from ICNP $1.0^{\circledR}$. Texto Contexto Enferm [Internet]. 2010 [citado 2013 jun. 11];19(1):54-63. Disponível em: http://www.scielo.br/pdf/tce/v19n1/v19n1a06.pdf

13. Dal Sasso GTM, Barra DCC, Paese F, Almeida SRW, Rios GC, Marinho $\mathrm{MM}$, et al. Computerized nursing process: methodology to establish associations between clinical assessment, diagnosis, interventions, and outcomes. Rev Esc Enferm USP [Internet]. 2013 [cited 2013 June 12];47(1):242-9. Available from: http://www.scielo.br/pdf/reeusp/v47n1/ en_a31v47n1.pdf

14. Barra DCC, Sasso GTMD, Monticelli M. Processo de enfermagem informatizado em unidade de terapia intensiva: uma prática educativa com enfermeiros. Rev Eletr Enferm [Internet]. 2009 [citado 2013 jun. 24];11(3):579-89. Disponível em: http://www.fen.ufg.br/revista/v11/n3/v11n3a15.htm

15. Abedellah FG, Levine E. Better patient care through nursing research. New York: MacMillan; 1965.

16. Tanscheit R. Sistemas Fuzzy [Internet]. Belo Horizonte: Departamento de Engenharia Elétrica da Pontifícia Universidade Católica de Minas Gerais; 2003 [citado 2013 jun. 12]. Disponível em: http://www2.ica.ele.puc-rio.br/Downloads/41/ LN-Sistemas\%20Fuzzy.pdf

17. Perfilieva I. Fuzzy IF-THEN rules from logical point of view. In: Proceedings the International Conference 9th Fuzzy Days in Dortmund, Germany, 2006 Sept. 18-20. Comput Intell Theory Apl [Internet]. 2006 [cited 2013 June 11];38:691-7. Available from: http://link.springer.com/ book/10.1007/3-540-34783-6

18. Pedreira MLG. Enfermagem para a segurança do paciente. Acta Paul Enferm [Internet]. 2009 [citado 2013 jun. 12];22(4). Disponível em: http://www.scielo.br/pdf/ape/ v22n4/a01v22n4.pdf
19. Camerini FG, Silva LD. Segurança do paciente: análise do preparo de medicação intravenosa em hospital da rede sentinela. Texto Contexto Enferm [Internet]. 2011 [citado 2013 jun. 12];20(1):41-9. Disponível em: http://www.scielo.br/ pdf/tce/v20n1/05.pdf

20. Vieira APM, Kurcgant P. Indicadores de qualidade no gerenciamento de recursos humanos em enfermagem: elementos constitutivos segundo percepção de enfermeiros. Acta Paul Enferm [Internet]. 2010 [citado 2013 jun. 12];23(1):11-5. Disponível em: http://www.scielo.br/pdf/ape/v23n1/02.pdf

21. U. S. Department of Health \& Human Services; Agency for Healthcare Research and Quality. AHRQ quality indicators: guide to patient safety indicators - version 3.1. [Internet]. 2007 [cited 2013 June 12]. Available from: http://www.qualityindicators.ahrq.gov

22. U. S. Institute of Medicine; National Academies. Crossing the quality chasm: a new health system for the 21st century. Washington: National Academies Press; 2001.

23. Gouvea CSD, Travassos C. Indicadores de segurança do paciente para hospitais de pacientes agudos: revisão sistemática. Cad Saúde Pública [Internet]. 2010 [citado 2013 jun. 13]; 26(6):1061-78. Disponível em: http://www.scielo.br/pdf/ csp/v26n6/02.pdf

24. Kontio $E$, Lundgren-Laine $H$, Kontio J, Korvenranta $H$, Salanterä S. Information utilization in tactical decision making of middle management health managers. Comput Inform Nurs. 2013;31(1):9-16.

25. Brokel JM, Schwichtenberg TJ, Wakefield DS, Ward MM, Shaw MG, Kramer JM. Evaluating clinical decision support rules as an intervention in clinician workflows with technology. Comput Inform Nurs. 2011;29(1):36-42.

26. Lundgrén-Laine $H$, Kontio $E$, Perttilä J, Korvenranta $H$, Forsström J, Salanterä S. Managing daily intensive care activities: an observational study concerning ad hoc decision making of charge nurses and intensivists. Crit Care. 2011;15(4):R188. 